ORIGINAL ARTICLE

\title{
Factors Associated with Accessibility in Seven Peruvian Primary Health Care Facilities
}

MARIO J. VALLADARES-GARRIDO ${ }^{1, A}$, LAURA M. CCOSCO-BLAS ${ }^{2, B}$, PAULA GUTIÉRREZ 3 ,B, PAOLA J. RAMOSRUPAY $^{2, B}$, ALIX X. RIVERA-PINTO ${ }^{3, B}$, ANDREA S. VELARDE-TELLO ${ }^{2, B}$, DEYANIRA VERTIZ-CUADRA ${ }^{2, B}$, FIORELLA INGA-BERROSPI ${ }^{3, C}$

${ }^{1}$ Universidad Continental, Lima, Perú

${ }^{2}$ Grupo de investigación CEMED-UPTC. Universidad Pedagógica y Tecnológica de Colombia- UPTC. Tunja, Colombia.

${ }^{3}$ Universidad Privada Norbert Wiener, Lima, Perú

a. Physician and Epidemiologist

b. Medical student

c. Physician and Health Management Specialist

Corresponding author: Fiorella Inga-Berrospi, M.D, MPH, Universidad Privada Norbert Wiener, Lima, Perú, Mobile: + 51941082162, Email: fiorella.inga@uwiener.edu.pe

\begin{abstract}
Introduction: There is limited evidence on factors associated with access to health primary health care services in users of marginal urban areas of Lima, Peru.

Objective: To determine factors associated with access to primary health care services in Lima, Peru.

Material and Methods: Cross-sectional study in users treated at seven primary health care facilities in a marginal urban area of Lima, Peru in 2019. A questionnaire was used to measure accessibility to health services; demographic and socioeconomic factors and characteristics of health services were investigated as well. Simple and multiple regression analyses were performed, estimating prevalence ratios.

Results: Out of a total of 150 participants, $85.2 \%$ had access to health services. Female gender was positively associated with access to health services (aPR:1.17, 95\% Cl:1.11-1.23). Secondary education (aPR:0.65, 95\% $\mathrm{Cl}: 0.44-0.98)$ and higher technical education or armed forces (aPR:0.64, 95\%Cl:0.46-0.89) were negatively associated with access to health services. On the other hand, we found that waiting time for care reduces the possibility of accessing health care; in case wait time is more than 30 minutes (aPR:0.83, 95\% Cl: 0.77-0.95), more than one hour (RPa:0.85, Cl95\%:0.75-0.95) and more than two hours (RPa:0.84, Cl95\%:0.75-0.93).

Conclusions: The majority of users treated at the Primary Health Care facilities had access to health services. Having a higher educational level and reporting a longer waiting time for care were associated with a lower frequency of accessibility, while being a woman was associated with a higher frequency of accessibility.

Key words: Health services, primary health care, health services accessibility, delivery of health care, public health.
\end{abstract}

\section{INTRODUCTION}

The National Health Services System (Sistema Nacional de Servicios de Salud, SNSS) in Peru was born in 1978 and initiated the reforms of the national health systems in many Latin American countries, which determined transcendental achievements to build equity (1). Despite this, there are currently no major reforms aimed at achieving access to comprehensive health care for the entire population, to develop and strength Primary Health Care (PHC) (1). The health system makes it possible to obtain a high degree of wellbeing, since it contributes to the improvement of the population's health, responds to its expectations in the face of financial adversities in regard to illness and disability. High or low efficiency of the performance of these functions explains the large gaps between national systems that work well and those that do not (2).

Access to health services, understood as the capacity to use health services when and where needed, has become one of the main challenges in some health systems in countries with insufficient income (3). Despite this, the great inequality that exists in the health sector continues to be a major concern in both industrialized and developing countries (4-6). These inequalities affect health status, the financing of public health expenditures and, specially, access to health services (1).
The literature on the factors that contribute to access to health is clear, some of them are the individual's own characteristics, the use of health services as well as the system's own characteristics (provision of services, availability of resources for the requirements of potential consumers, waiting time for care) (3,7-9); but there is limited evidence on accessibility and the influencing factors in health facilities in PHC (10-12).

Therefore, the objective of the present study was to determine the factors associated with accessibility in seven primary health care facilities in Lima, Peru.

\section{MATERIALS AND METHODS}

Study design: A cross-sectional research was conducted at seven health facilities (C.S Conde de la Vega, C.S Pachacamac, C.S Guayabo, C.S Picapiedra, C.S Magdalena, C.S Libertad and C.S Chosica) of PHC in Lima, Peru from January to March 2019.

Population and Sample: The population consisted of 150 outpatients treated at seven PHC facilities in Lima, Peru from January to March 2019. We used convenience nonprobability sampling.

Those outpatients seen at seven health facilities of the first level of health care and who gave consent for the research were included. Those outpatients who had any noticeable communication disability were excluded. 
Study Procedures: An authorization was requested from each director of the seven health facilities by means of an official document issued by Norbert Wiener University. In addition, a team of medical students was recruited to carry out the data collection in each health facility, supervised by a physician specialized in the area of public management. The instrument was filled out by the external users in the waiting rooms of each health facility during working hours in the morning and afternoon shifts. The approximate time for filling out the instrument was 10 minutes. Subsequently, pre-digitization quality control was performed, and then, a data entry sheet was designed on Microsoft Excel.

Instrument and Variables: We used a questionnaire submitted to a content validation process by a panel of experts in the research topic. The questionnaire had four sections: I) 6 questions about sociodemographic factors, II) 4 questions about socioeconomic factors, III) 5 questions about Family functioning scale (APGAR) and IV) 11 questions about characteristics of health services.

The dependent variable was accessibility to health services. This variable was defined as the presence or absence of access to consultations at the health facility during the last year. The response options were yes and no.

The independent variables were demographic, socioeconomic and health services variables.

The demographic variables were: gender (male or female), age (years of age), marital status (single, married, cohabiting, widowed and divorced), language (Spanish, English), household size (number reported numerically), and basic services (water-energy-sanitation-phone).

The socioeconomic variables were: monthly family income (amount in soles), educational level (cannot read or write, complete primary school, incomplete primary school, incomplete secondary school, complete secondary school, private institutes, armed forces, complete university, incomplete university, master's degree, diploma, doctorate), residence (Lima and provinces), employment type (permanent, temporary, unemployed).

The characteristics of the explored health services were accessibility to health services, enrollment in the Comprehensive Health Insurance (Seguro Integral de Salud-SIS), having a family member/friend who takes care of the patient when he/she is sick, explanation of the condition, understanding of the condition, having enough money to buy medicines, waiting time prior to care, consultation time and perception of the consultation, facilities and service at the health facility).

Statistical Analysis and Power Calculation: The descriptive analysis of numerical variables evaluated the assumption of normality graphically and analytically, according to which means and standard deviation, or otherwise, median and interquartile range were reported.

The bivariate analysis evaluated the assumption of expected frequencies and according to them, the Chisquare test of independence was used, to analyze the association between the independent variables of interest and accessibility to health services. In addition, the Fischer's exact test was used, after the evaluation of assumptions.
Simple and multiple regression analysis estimated crude (cPR) and adjusted prevalence ratios (aPR). Generalized linear models (GLM), Poisson distribution, log link function and robust variance were used to identify associations between accessibility and demographic, socioeconomic and health services characteristics, using health facility as a cluster. Confidence intervals at $95 \%$ were used. P-values less than 0.05 were reported as statistically significant.

The statistical analysis was performed in STATA v.15.0 (StataCorp LP, College Station, TX, USA).

Ethical Considerations: The protocol of this research was approved by the Ethics Committee of Norbert Wiener University (UNW) of Lima. The confidentiality of the participants was preserved using codes. Written consent was requested to participate in the research.

\section{RESULTS}

Out of 150 participants, the majority were female (81.3\%) and the median age was 32 years (23-42). Most of the participants had access to electricity $(95.3 \%)$, water (94\%) and sanitation (80\%). Table 01.

\section{TABLES}

Table 1: Demographic and socioeconomic characteristics of patients treated at seven FLHC facilities in a marginal urban area of Lima, 2019.

\begin{tabular}{|c|c|c|}
\hline Characteristics & $\mathbf{N}$ & $\%$ \\
\hline \multicolumn{3}{|l|}{ Marital staus } \\
\hline \begin{tabular}{l|l} 
Single \\
\end{tabular} & 48 & 32.0 \\
\hline Married & 29 & 19.3 \\
\hline Cohabiting & 60 & 40.0 \\
\hline Widowed & 8 & 5.3 \\
\hline Divorced & 5 & 3.3 \\
\hline Spanish language & 150 & 100.0 \\
\hline Quechua language & 21 & 14.0 \\
\hline English language & 11 & 7.3 \\
\hline People living at home & 4 & 3 a 5 \\
\hline Household monthly income (soles)† & 1200 & $850-2000^{*}$ \\
\hline \multicolumn{3}{|l|}{ Employment } \\
\hline \begin{tabular}{l|l} 
Permanent \\
\end{tabular} & 49 & 32.7 \\
\hline Temporary & 29 & 19.3 \\
\hline \begin{tabular}{l|l} 
& Unemployed \\
\end{tabular} & 72 & 48.0 \\
\hline \multicolumn{3}{|l|}{ Educational level $\dagger$} \\
\hline Cannot read or write & 1 & 0.7 \\
\hline Complete primary & 7 & 4.7 \\
\hline Incomplete primary & 3 & 2.0 \\
\hline Incomplete secondary & 17 & 11.4 \\
\hline Complete secondary & 62 & 41.6 \\
\hline Private institutes & 30 & 20.1 \\
\hline Armed Forces & 2 & 1.3 \\
\hline Complete university & 15 & 10.1 \\
\hline Incomplete university & 9 & 6.0 \\
\hline \begin{tabular}{l|l} 
& Master's degree, diploma, doctorate
\end{tabular} & 3 & 2.0 \\
\hline \multicolumn{3}{|l|}{ Procedence } \\
\hline Lima & 66 & 44.0 \\
\hline \begin{tabular}{l|l} 
Provinces/abroad \\
\end{tabular} & 84 & 56.0 \\
\hline \multicolumn{3}{|c|}{$\begin{array}{l}\text { † The sum of some values may not be } 150 \text { due to missing data. } \\
\text { * Median (percentil } 25 \text { to percentil } 75 \text { ) }\end{array}$} \\
\hline
\end{tabular}

Regarding the characteristics of health services, $75.2 \%$ were enrolled in SIS insurance and more than half of them purchased their medicines at the health center (56\%). Most of them wait for more than two hours before medical attention (44\%) and consider that the consultation length is 
average (40.9\%). Finally, $52.7 \%$ mentioned that the health facilities are average and that the provided service is good $(49.3 \%)$. A total of $85.2 \%$ of the respondents had received care during the last year. Table 02 .

Table 2: Characteristics of health services in patients attended at primary health care facilities in the marginal urban area of Lima, 2019.

\begin{tabular}{|c|c|c|}
\hline Characteristics & $\mathbf{N}$ & $\%$ \\
\hline Enrolled in SIS $\uparrow$ & 37 & 24.8 \\
\hline \multicolumn{3}{|l|}{$\begin{array}{l}\text { Is there a relative/friend who takes care of } \\
\text { you when you get sick } \\
\text { ?† }\end{array}$} \\
\hline Non-medical professional & 43 & 28.9 \\
\hline Medical professional & 33 & 22.2 \\
\hline \multicolumn{3}{|l|}{$\begin{array}{l}\text { Did you receive an explanation about your } \\
\text { condition in consultation at the health } \\
\text { facility? } \dagger\end{array}$} \\
\hline Never & 4 & 2.8 \\
\hline Sometimes & 41 & 28.3 \\
\hline Always & 100 & 69.0 \\
\hline \multicolumn{3}{|l|}{$\begin{array}{l}\text { Did you understand when the medical staff } \\
\text { explained about your condition? } \dagger\end{array}$} \\
\hline Did not understand & 4 & 2.8 \\
\hline Partially understood & 61 & 42.4 \\
\hline Completely understood & 79 & 54.9 \\
\hline Get medicines at stores & 115 & 76.7 \\
\hline Get medicines at the health facility & 84 & 56.0 \\
\hline Get medicines at the municipal pharmacy & 45 & 30.0 \\
\hline Get medicines in health campaigns & 3 & 2.0 \\
\hline $\begin{array}{l}\text { Is your family income enough to buy } \\
\text { prescription medicines at the health center? }\end{array}$ & 83 & 55.3 \\
\hline \multicolumn{3}{|l|}{$\begin{array}{l}\text { Wait time before consultation at the health } \\
\text { facility }\end{array}$} \\
\hline Instantaneous & 3 & 2.0 \\
\hline 5-10 minutes & 3 & 2.0 \\
\hline $10-15$ minutes & 8 & 5.3 \\
\hline $15-20$ minutes & 10 & 6.7 \\
\hline $20-30$ minutes & 8 & 5.3 \\
\hline More than 30 minutes & 17 & 11.3 \\
\hline More than 1 hour & 35 & 23.3 \\
\hline More than 2 hours & 66 & 44.0 \\
\hline \multicolumn{3}{|l|}{ Consultation length † } \\
\hline Extremely short & 6 & 4.0 \\
\hline short & 14 & 9.4 \\
\hline Average & 61 & 40.9 \\
\hline Adequate & 58 & 38.9 \\
\hline Very adequate & 10 & 6.7 \\
\hline \multicolumn{3}{|l|}{ Health facilities } \\
\hline Very poor & 6 & 4.0 \\
\hline poor & 18 & 12.0 \\
\hline Regular & 79 & 52.7 \\
\hline good & 41 & 27.3 \\
\hline Very good & 6 & 4.0 \\
\hline \multicolumn{3}{|l|}{ Health facility service } \\
\hline Very poor & 3 & 2.0 \\
\hline poor & 15 & 10.0 \\
\hline Regular & 50 & 33.3 \\
\hline good & 74 & 49.3 \\
\hline Very good & 8 & 5.3 \\
\hline Accesibilty & 127 & 85.2 \\
\hline \multicolumn{3}{|c|}{ † The sum of some values may not be 150 due to missing data. } \\
\hline $\begin{array}{llll}\text { SIS: Sistema Integral de Salud (Compre } \\
\text { Insurance) }\end{array}$ & hensi & Health \\
\hline
\end{tabular}

Table 03 shows the results of the bivariate analysis, which allowed us to find that gender $(p=0.035)$, having SIS insurance $(p=0.049)$ and getting medicines at the health facility $(p=0.012)$ were associated with a higher frequency of accessibility to health services.

On the other hand, getting medicines at the municipal pharmacy $(p=0.028)$ and wait time before consultation at the health center $(p=0.045)$ were associated with a lower frequency of accessibility.

Table 3: Factors associated with accessibility to health services in primary health care patients in a marginal urban area of Lima, 2019.

\begin{tabular}{|c|c|c|c|}
\hline \multirow{3}{*}{ Variables } & \multicolumn{2}{|c|}{ Accessibility to health services? } & \multirow{3}{*}{$p$} \\
\hline & \multirow{2}{*}{$\begin{array}{l}\text { No }(n=22) \\
n(\%)\end{array}$} & \multirow{2}{*}{$\begin{array}{l}\begin{array}{l}\text { Yes } \\
(n=127)\end{array} \\
n(\%)\end{array}$} & \\
\hline & & & \\
\hline Gender $^{\star \star}$ & & & 0.035 \\
\hline Male & $8(28.6)$ & $20(71.4)$ & \\
\hline \begin{tabular}{|l|} 
Female \\
\end{tabular} & $14(11.6)$ & $107(88.4)$ & \\
\hline Enrolled in SIS*† & & & 0.049 \\
\hline No & $9(25.0)$ & $27(75.0)$ & \\
\hline \begin{tabular}{l|l} 
Yes \\
\end{tabular} & $13(11.6)$ & $99(88.4)$ & \\
\hline $\begin{array}{l}\text { Get medicines at the } \\
\text { health facility* }\end{array}$ & & & 0.012 \\
\hline No & $15(23.1)$ & $50(76.9)$ & \\
\hline Yes & $7(8.3)$ & $77(91.7)$ & \\
\hline $\begin{array}{l}\text { Get medicines at the } \\
\text { municipal pharmacy* }\end{array}$ & & & 0.028 \\
\hline \begin{tabular}{l|l} 
No \\
\end{tabular} & $11(10.6)$ & $93(89.4)$ & \\
\hline Yes & $11(24.4)$ & $34(75.6)$ & \\
\hline $\begin{array}{l}\text { Time before being seen } \\
\text { at the health facility** } \dagger\end{array}$ & & & 0.045 \\
\hline \begin{tabular}{l|l} 
Instantaneous \\
\end{tabular} & $0(0.0)$ & $3(100.0)$ & \\
\hline 5-10 minutes & $3(100.0)$ & $0(0.0)$ & \\
\hline $10-15$ minutes & $1(12.5)$ & $7(87.5)$ & \\
\hline $15-20$ minutes & $1(10.0)$ & $9(90.0)$ & \\
\hline $20-30$ minutes & $1(12.5)$ & $7(87.5)$ & \\
\hline $\begin{array}{lll}\begin{array}{l}\text { More } \\
\text { minutes }\end{array} & \text { than } 30 \\
\end{array}$ & $4(23.5)$ & $13(76.5)$ & \\
\hline More than 1 hour & $4(11.4)$ & $31(88.6)$ & \\
\hline More than 2 hours & $8(12.3)$ & $57(87.7)$ & \\
\hline \multicolumn{4}{|c|}{${ }^{*}$ Chi-2 test of independence } \\
\hline \multicolumn{4}{|c|}{${ }^{* *}$ Fischer's exact test } \\
\hline † The sum of some valu & ay no & to miss & \\
\hline
\end{tabular}

During the simple regression analysis, it was found that female gender (cPR:1.24), between 6 to 10 people in the household (cPR:1.13), having SIS insurance (cPR:1.18), getting medicines at the health facility (cPR:1.19) or in health campaigns (cPR:1.18), and perceiving consultation length to be adequate (cPR:1.12) were positively associated with accessibility to health services. Table 04 .

The multiple regression analysis of sociodemographic characteristics showed that female gender was positively associated with access to health services (aPR:1.17, $95 \% \mathrm{Cl}: 1.11-1.23, \mathrm{p}<0.001)$. Also, secondary education level (aPR:0.65, 95\%Cl:0.44-0.98, $\mathrm{p}=0.040$ ) and higher technical education/armed forces (aPR:0.64, 95\%Cl:0.46$0.89, p=0.008$ ) were negatively associated with having access to health services. On the other hand, it was found that waiting time for care at the health facility reduced the possibility of access to health care, in the waiting period of more than 30 minutes (aPR:0.83, 95\%Cl:0.77-0.95, $\mathrm{p}<0.001$ ), more than one hour (aPR:0.85, 95\% Cl:0.75-0.95, $\mathrm{p}=0.004$ ) and more than two hours (aPR:0.84, 95\%Cl:0.750.93, $p=0.001$ ). Table 04 . 
Table 04. Factors independently associated with accessibility to health services in multiple regression analysis.

\begin{tabular}{|c|c|c|c|c|c|c|}
\hline \multirow{2}{*}{ Variables } & \multicolumn{3}{|c|}{ Simple regression } & \multicolumn{3}{|c|}{ Multiple regression } \\
\hline & cPR & $95 \% \mathrm{Cl}$ & $p^{*}$ & $\begin{array}{l}\mathrm{aPR} \\
\end{array}$ & $95 \% \mathrm{Cl}$ & $p^{*}$ \\
\hline \multicolumn{7}{|l|}{ Gender } \\
\hline \begin{tabular}{l|l} 
& Male
\end{tabular} & Ref. & & & \begin{tabular}{|l|} 
Ref. \\
\end{tabular} & & \\
\hline Female & 1.24 & $1.10-1.39$ & $<0.001$ & 1.17 & $1.11-1.23$ & $<0.001$ \\
\hline \multicolumn{7}{|l|}{ Marital status } \\
\hline Single & Ref. & & & Ref. & & \\
\hline Married & 0.97 & $0.92-1.03$ & 0.338 & 1.03 & $0.91-1.17$ & 0.636 \\
\hline Cohabiting & 1.04 & $0.93-1.16$ & 0.516 & 1.04 & $0.98-1.11$ & 0.160 \\
\hline Widowed & 0.88 & $0.56-1.40$ & 0.590 & 0.79 & $0.54-1.16$ & 0.232 \\
\hline Divorced & 0.94 & $0.90-0.98$ & 0.004 & 0.94 & $0.84-1.05$ & 0.249 \\
\hline \multicolumn{7}{|l|}{ Household size } \\
\hline 1 to 5 & Ref. & & & \begin{tabular}{|l} 
Ref. \\
\end{tabular} & & \\
\hline 6 to 10 & 1.13 & $1.02-1.25$ & 0.019 & 1.04 & $0.99-1.10$ & 0.083 \\
\hline 11 to more & 1.02 & $0.79-1.33$ & 0.863 & 1.01 & $0.65-1.59$ & 0.953 \\
\hline \multicolumn{7}{|l|}{ Educational level $^{\star \star}$} \\
\hline Cannot read or write & Ref. & & & Ref. & & \\
\hline Primary & 0.90 & $0.72-1.13$ & 0.355 & 0.74 & $0.47-1.16$ & 0.188 \\
\hline Secondary & 0.87 & $0.82-0.93$ & $<0.001$ & 0.65 & $0.44-0.98$ & 0.040 \\
\hline Higher technical education / armed forces & 0.81 & $0.70-0.95$ & 0.007 & 0.64 & $0.46-0.89$ & 0.008 \\
\hline Higher university / postgraduate & 0.85 & $0.76-0.94$ & 0.002 & 0.73 & $0.50-1.06$ & 0.101 \\
\hline Enrolled in SIS & 1.18 & $1.10-1.26$ & $<0.001$ & 1.05 & $0.98-1.13$ & 0.170 \\
\hline \multicolumn{7}{|c|}{$\begin{array}{l}\text { Did medical staff explain your condition during } \\
\text { consultation? }\end{array}$} \\
\hline Never & Ref. & & & Ref. & & \\
\hline Sometimes & 0.88 & $0.79-0.98$ & 0.018 & 0.97 & $0.81-1.15$ & 0.690 \\
\hline Always & 0.88 & $0.81-0.95$ & 0.001 & 0.96 & $0.84-1.09$ & 0.512 \\
\hline \multicolumn{7}{|c|}{$\begin{array}{l}\text { Did you understand when the health care staff } \\
\text { explained your condition? }\end{array}$} \\
\hline Did not understand & Ref. & & & \begin{tabular}{|l|} 
Ref. \\
\end{tabular} & & \\
\hline Partially understood & 0.90 & $0.82-0.99$ & 0.024 & 0.80 & $0.58-1.09$ & 0.162 \\
\hline Totally understood & 0.87 & $0.78-0.97$ & 0.015 & 0.77 & $0.52-1.13$ & 0.180 \\
\hline Get the medicines at the health facility & 1.19 & $1.10-1.29$ & $<0.001$ & 1.06 & $0.95-1.17$ & 0.296 \\
\hline Get the medicines in health campaigns ${ }^{\star \star}$ & 1.18 & $1.11-1.25$ & $<0.001$ & 1.06 & $0.88-1.27$ & 0.545 \\
\hline \multicolumn{7}{|l|}{ Waiting time before consultations } \\
\hline \begin{tabular}{l|l} 
Instantaneous \\
\end{tabular} & Ref. & & & \begin{tabular}{|l|} 
Ref. \\
\end{tabular} & & \\
\hline $5-10$ minutes & 2.15E-07 & $\begin{array}{l}6.33 \mathrm{E}-08 \\
7.30 \mathrm{E}-07\end{array}$ & $<0.001$ & 2.39E-07 & $\begin{array}{l}5.12 \mathrm{E}-08-1.12 \mathrm{E}- \\
06\end{array}$ & $<0.001$ \\
\hline $10-15$ minutes & 0.88 & $0.65-1.18$ & 0.387 & 0.92 & $0.76-1.12$ & 0.399 \\
\hline $15-20$ minutes & 0.90 & $0.74-1.09$ & 0.280 & 0.99 & $0.94-1.04$ & 0.613 \\
\hline $20-30$ minutes & 0.88 & $0.64-1.20$ & 0.401 & 0.95 & $0.85-1.07$ & 0.403 \\
\hline More than 30 minutes & 0.76 & $0.62-0.95$ & 0.015 & 0.83 & $0.77-0.89$ & $<0.001$ \\
\hline More than 1 hour & 0.89 & $0.79-1.00$ & 0.044 & 0.85 & $0.75-0.95$ & 0.004 \\
\hline More than 2 hours & 0.88 & $0.84-0.91$ & $<0.001$ & 0.84 & $0.75-0.93$ & 0.001 \\
\hline \multicolumn{7}{|l|}{ Consultation length } \\
\hline Extremely short & Ref. & & & Ref. & & \\
\hline short & 0.94 & $0.76-1.16$ & 0.582 & 0.90 & $0.74-1.09$ & 0.281 \\
\hline Regular & 0.98 & $0.84-1.16$ & 0.841 & 0.97 & $0.78-1.20$ & 0.761 \\
\hline Adequate & 1.12 & $1.07-1.17$ & $<0.001$ & 1.00 & $0.92-1.09$ & 0.922 \\
\hline Very adequate & 0.84 & $0.53-1.32$ & 0.450 & 0.92 & $0.71-1.20$ & 0.549 \\
\hline
\end{tabular}

\section{DISCUSSION}

In our study we found that almost nine out of ten participants had access to health services (85.2\%). However, several studies in developing countries such as Peru highlight the need to increase the accessibility to care required for users' well-being (13-20), as confirmed in a recent study which identified that patients from $\mathrm{PHC}$ had little access to mental health care services (21). It also differs from what was described by Seclén-Palacin and
Darras et al, who remarked the problem of the Peruvian population when accessing health services, taking into account that in that study there is a larger and randomized sample, having a clearer picture of what happens in the country (7). An investigation developed in Spanish primary care facilities found that more than $90 \%$ had accessibility to spirometry (22).

The probable explanation for the high frequency of accessibility is that the reform of the Peruvian health system, which seeks to eliminate the barriers between the 
accessibility to the service and the population's needs, has increased the coverage of this service to people (23). Furthermore, the acceptable proportion of accessibility could be linked to having the Comprehensive Health Insurance (SIS), since out of the total number of participants who had access to health services, $88.7 \%$ were enrolled in this social insurance.

Patients who reported waiting more than half an hour, one hour and more than two hours to receive care in $\mathrm{PHC}$ facilities were less likely to go to a consultation in the last year. This result is consistent with what was described by Figueroa and Cavalcanti, who explained that waiting time to receive care constitutes a socio-organizational barrier to access health services (24). This relationship could exist due to the fact that the barrier is not only present at the moment of receiving the service, but also everything that is involved for the user to obtain the service and go to the health center. Thus, obtaining this service loses quality and importance for a patient who must spend so much time just to access the necessary care (24), resulting in patients who do not show up or simply a decrease in the number of people willing to receive the service when it is their turn to receive it (25). Therefore, this association could be explained by multiple barriers of a geographical and socioeconomic nature, as well as characteristics related to patients and their own diseases.

Regarding the evaluated socio-demographic characteristics, we found that women were more likely to have access to health services. Rosa-Jimenez et al. found that the being a female showed a higher proportion of consultations in primary health care, as well as in the request for appointments. This could be explained by the fact that women are more aware of their health and that they are more often reported with chronic diseases (26).

The improvements in the Peruvian health system could be another important factor, which benefits pregnant women as well as newborns by enrolling them in the SIS insurance program, partially promoting the access to health services for this gender over men (23). It is also important to highlight that $81.5 \%$ of the sample is comprised of women, which makes it difficult to have an overall view of both sexes and to take this variable as an important factor when accessing health services.

Finally, patients who reported secondary and higher technical/armed forces education had a lower frequency of access to health services. No previous studies have been found that evaluate this association; however, the possible explanation for the obtained result is the lack of time due to their work, as well as the little attention they pay to their health condition.

The importance of our findings is that the study shows the accessibility in the urban-marginal population, which is an important reference when showing the progress in the improvements implemented by the government and carrying out studies of the same type at the Latin American level to show the current situation of Peru. The findings of the study are also relevant for future research on the rural versus urban-marginal situation.

However, some limitations of our study should be mentioned. Selection bias, since we cannot infer the results to the entire population treated at PHC health facilities, as we only surveyed people who were in the facility, leaving aside a large part of the population that uses the services, but were not evaluated due to various factors associated with accessibility.

We recommend that future studies take into account a slightly more equitable population in terms of gender. We also recommend extending the studies to rural areas in order to have a complete view of service accessibility. Likewise, not conducting the study in the service are could be taken into account, as this could lead to information bias when the user is already accessing the services.

\section{CONCLUSIONS}

We conclude that accessibility to PHC services in seven $\mathrm{PHC}$ health facilities is favorable. Waiting time longer than half an hour, one hour and more than two hours; as well as having secondary and higher technical/armed forces education were negatively associated with access to health services, While being a woman was positively associated with accessibility to health services.

Conflicts of Interest: The authors declare that they have no conflicts of interest.

\section{REFERENCES}

1. Sánchez-Moreno F. El sistema nacional de salud en el Perú. Revista Peruana de Medicina Experimental y Salud Publica. octubre de 2014;31(4):747-53.

2. González LM, Peñaloza RE, Matallana MA, Gil F, GómezRestrepo C, Landaeta APV. Factores que determinan el acceso a servicios de salud mental de la población adulta en Colombia. Revista Colombiana de Psiquiatría. 1 de diciembre de 2016;45:89-95.

3. Restrepo-Zea JH, Silva-Maya C, Andrade-Rivas F, VHDover R. Acceso a servicios de salud: análisis de barreras y estrategias en el caso de Medellín, Colombia. Revista Gerencia y Políticas de Salud. diciembre de 2014;13(27):242-65.

4. Mejía-Mejía A, Sánchez-Gandur AF, Tamayo-Ramírez JC. Equidad en el Acceso a Servicios de Salud en Antioquia, Colombia. Revista de Salud Pública. 2007;9(1):26-38.

5. Lostao L, Regidor E, Calle ME, Navarro P, Domínguez V. Evolución de las diferencias socioeconómicas en la utilización y accesibilidad de los servicios sanitarios en España entre 1987 y 1995/97. Revista Española de Salud Pública. abril de 2001;75(2):115-28.

6. Mendoza-Sassi R, Béria JU. Utilización de los servicios de salud: una revisión sistemática sobre los factores relacionados. Cadernos de Saúde Pública. agosto de 2001;17(4):819-32.

7. Seclén-Palacin J, Darras C. Satisfacción de usuarios de los servicios de salud: factores sociodemográficos y de accesibilidad asociados: Perú, 2000. Anales de la Facultad de Medicina. junio de 2005;66(2):127-41.

8. Mantilla ARLT, García AEO, llanzo MPQ. Factores asociados al grado de satisfacción del usuario del consultorio externo de gastroenterología del Hospital Central de la Fuerza Aérea del Perú. Mayo, 2014. 1 [Internet]. 15 de agosto de 2018 [citado 4 de junio de 2019];17(34). Disponible https://revistas.javeriana.edu.co/index.php/gerepolsal/article/ view/23090

9. Macniven $R$, Hunter $K$, Lincoln M, O'Brien $C$, Jeffries $T L$, Shein G, et al. Accessibility of Primary, Specialist, and Allied Health Services for Aboriginal People Living in Rural and Remote Communities: Protocol for a Mixed-Methods Study. JMIR Res Protoc. 28 de febrero de 2019;8(2):e11471. 
10. Knight BG, Winterbotham S. Rural and urban older adults' perceptions of mental health services accessibility. Aging Ment Health. 14 de febrero de 2019;1-7.

11. Thummapol O, Park T, Barton S. Exploring health services accessibility by indigenous women in Asia and identifying actions to improve it: a scoping review. Ethn Health. 3 de mayo de 2018;1-20.

12. Ridde V, Girard JE. [Twelve years after the Bamako initiative: facts and political implications for equity in health services accessibility for indigent Africans]. Sante Publique. marzo de 2004;16(1):37-51.

13. Obando Medina C, Kullgren G, Dahlblom K. A qualitative study on primary health care professionals' perceptions of mental health, suicidal problems and help-seeking among young people in Nicaragua. BMC Fam Pract. 2 de julio de 2014:15:129.

14. Scorza P, Cutipe Y, Mendoza M, Arellano C, Galea JT, Wainberg ML. Lessons From Rural Peru in Integrating Mental Health Into Primary Care. Psychiatr Serv. 1 de enero de 2019;70(1):82-4.

15. Scharager Goldenberg J, Molina Aguayo ML. [Work features of the psychologist in the primary health care centers of the public health care system in Chile]. Rev Panam Salud Publica. septiembre de 2007;22(3):149-59.

16. Diez-Canseco F, Toyama M, Ipince A, Perez-Leon S, Cavero V, Araya R, et al. Integration of a Technology-Based Mental Health Screening Program Into Routine Practices of Primary Health Care Services in Peru (The Allillanchu Project): Development and Implementation. J Med Internet Res. 15 de 2018;20(3):e100.

17. Quintanilla AE, Taype-Rondan Á, Lazo-Porras M, HerreraAñazco P. Obesity markers associated to albuminuria in a primary care center in Lima, Perú. Endocrinol Diabetes Nutr. julio de 2017;64(6):295-302.

18. Borba CPC, Gelaye B, Zayas L, Ulloa M, Lavelle J, Mollica $\mathrm{RF}$, et al. Making strides towards better mental health care in Peru: Results from a primary care mental health training. Int J Clin Psychiatry Ment Health. abril de 2015;3(1):9-19.
19. Iwami M, Petchey R. A CLAS act? Community-based organizations, health service decentralization and primary care development in Peru. Local Committees for Health Administration. J Public Health Med. diciembre de 2002;24(4):246-51.

20. Diez-Canseco $F$, Ipince A, Toyama M, Benate-Galvez $Y$, Galán-Rodas E, Medina-Verástegui JC, et al. [Integration of mental health and chronic non-communicable diseases in Peru: challenges and opportunities for primary care settings]. Rev Peru Med Exp Salud Publica. 2014;31(1):131-6.

21. Cavero V, Diez-Canseco F, Toyama M, Flórez Salcedo G, Ipince A, Araya R, et al. Provision of mental health care within primary care in Peru: A qualitative study exploring the perspectives of psychologists, primary health care providers, and patients. Wellcome Open Res. 2018;3:9.

22. Llauger MA, Rosas A, Burgos F, Torrente E, Tresserras R, Escarrabill $\mathrm{J}$, et al. [Accesibility and use of spirometry in primary care centers in Catalonia]. Aten Primaria. julio de 2014;46(6):298-306.

23. Velásquez A, Suarez D, Nepo-Linares E. Reforma del sector salud en el Perú: derecho, gobernanza, cobertura universal y respuesta contra riesgos sanitarios. Revista Peruana de Medicina Experimental y Salud Publica. julio de 2016;33(3):546-55.

24. Figueroa Pedraza D, Cavalcanti Costa GM. Accesibilidad a los servicios públicos de salud: la visión de los usuarios de la Estrategia Salud de la Familia. Enfermería Global. enero de 2014;13(33):267-78.

25. Tomasi E, Facchini LA, Thumé E, Piccini RX, Osorio A Silveira DS da, et al. Características da utilização de serviços de atenção básica à saúde nas regiões Sul e Nordeste do Brasil: diferenças por modelo de atenção. Ciência \&amp; Saúde Coletiva. noviembre de 2011;16(11):4395-404.

26. Rosa-Jiménez F, Montijano Cabrera AM, Ília Herráiz Montalvo C, Zambrana García JL. ¿Solicitan las mujeres más consultas al área médica que los hombres? Anales de Medicina Interna. noviembre de 2005;22(11):515-9. 